\title{
Hubungan Perilaku Sedentary dengan Indeks Massa Tubuh dan Tekanan Darah serta Denyut Jantung pada Pegawai Struktural dan Administrasi RSUD Provinsi Sulawesi Utara
}

\author{
Caesario S. J. Walukouw, ${ }^{1}$ Christopher Lampah, ${ }^{2}$ Joudy Gessal ${ }^{2}$
}

\author{
${ }^{1}$ Program Studi Pendidikan Dokter Fakultas Kedokteran Universitas Sam Ratulangi Manado \\ ${ }^{2}$ Ilmu Kedokteran Fisik Dan Rehabilitasi Fakultas Kedokteran Universitas Sam Ratulangi \\ Manado \\ Email: cwalukouw@gmail.com
}

\begin{abstract}
Due to high technology, sedentary behavior develops worldwide. Some consequences that might arise due to sedentary behavior inter alia increases in body mass index, blood pressure, and heart rate. The prevalences of obesity and high blood pressure in North Sulawesi are the highest ones in Indonesia. This study was aimed to identify the relationship between sedentary behavior and body mass index (BMI), blood pressure as well as heart rate among structural and administrative employees of North Sulawesi Regional Hospital as subjects. This was an analytical and observational study with a cross sectional design. Direct observation was performed on all subjects. The results showed that there were 37 employees as subjects. There was a strong correlation between sedentary behavior and blood pressure $(\mathrm{r}=0.684)$; a negative and very weak correlation between sedentary behavior and BMI $(\mathrm{r}=-$ $0.101)$; and a very strong correlation between sedentary behavior and heart rate $(r=0.796)$. In conclusion, there were relationships between sedentary behavior and blood pressure as well as heart rate. Albeit, there was no relationship between sedentary behavior and body mass index Keywords: sedentary behavior, body mass index, blood pressure, heart rate
\end{abstract}

\begin{abstract}
Abstrak: Dengan kemajuan teknologi maka perilaku sedentary makin meningkat di seluruh dunia. Beberapa akibat yang dapat terjadi akibat perilaku sedentary ialah meningkatnya indeks massa tubuh (IMT), tekanan darah, dan denyut jantung. Prevalensi obesitas dan tekanan darah tinggi di Sulawesi Utara ialah yang tertinggi di seluruh Indonesia. Penelitian ini bertujuan untuk mengetahui hubungan antara perilaku sedentary dengan IMT, tekanan darah, serta denyut jantung pada pegawai struktural dan administrasi RSUD Provinsi Sulawesi Utara. Jenis penelitian ialah analitik observasional dengan desain potong lintang. Pada penelitian ini dilakukan pengamatan langsung terhadap subyek penelitian yaitu pegawai struktural dan administrasi RSUD Provinsi Sulawesi Utara yang memenuhi kriteria inklusi. Hasil penelitian mendapatkan korelasi kuat antara perilaku sedentary dengan tekanan darah $(\mathrm{r}=0,684)$; korelasi negatif yang sangat lemah antara perilaku sedentary dengan IMT $(\mathrm{r}=-0,101)$; dan korelasi sangat kuat antara perilaku sedentary dengan denyut jantung $(r=0,796)$. Simpulan penelitian ini ialah terdapat hubungan antara perilaku sedentary dengan tekanan darah dan denyut jantung tetapi tidak terdapat hubungan antara perilaku sedentary dan indeks massa tubuh Kata kunci: perilaku sedentary, indeks massa tubuh, tekanan darah, denyut jantung
\end{abstract}

\section{PENDAHULUAN}

Perilaku sedentary adalah perilaku duduk atau berbaring selain tidur baik di tempat kerja, di rumah atau di alat transportasi. ${ }^{1}$ Penyebab sedentary meliputi jenis pekerjaan, hobi, fasilitas, kebiasaan, dan kurang berolahraga. ${ }^{2}$ Menurut WHO, seki$\operatorname{tar} 3,2$ juta kematian setiap tahun disebabkan oleh aktivitas fisik yang tidak memadai. Terdapat $60-85 \%$ orang di dunia baik 
di negara maju maupun negara ber-kembang menjalani perilaku sedentary, yang menjadikannya sebagai salah satu masalah kesehatan masyarakat yang lebih serius namun tidak cukup ditangani saat ini. ${ }^{3}$

Perilaku sedentary meningkatkan risiko penyakit kardiovaskular, diabetes, dan obesitas, serta meningkatkan risiko kanker usus besar, tekanan darah tinggi, osteoporosis, gangguan lipid, depresi, kecemasan bahkan menyebabkan kematian. ${ }^{2}$

Menurut World Health Organization (WHO) obesitas adalah suatu kondisi di mana seseorang mengalami pertambahan lemak berlebih yang didasarkan pada indeks massa tubuh (IMT). ${ }^{4}$ Perilaku sedentary dapat menyimpan banyak kalori dan mengeluarkan sedikit energi sehingga menyebabkan obesitas. ${ }^{5}$ Menurut Riset Kesehatan Dasar RI pada tahun 2018 prevalensi obesitas pada dewasa $>18$ tahun di Indonesia tertinggi di Sulawesi Utara $(30,2 \%)^{6}$

Hipertensi (tekanan darah tinggi) adalah peningkatan tekanan darah sistolik lebih dari $140 \mathrm{mmHg}$ dan tekanan darah diastolik lebih dari $90 \mathrm{mmHg}$ pada waktu dua kali pengukuran tekanan darah dalam rentang waktu lima menit pada keadaan tenang atau istirahat. ${ }^{7}$ Menurut Riset Kesehatan Dasar RI pada tahun 2018 prevalensi hipertensi berdasarkan diagnosis dokter pada penduduk berusia lebih dari 18 tahun di Indonesia menunjukkan Sulawesi Utara memiliki prevalensi tertinggi yaitu $13,2 \%{ }^{6}$

Denyut jantung merupakan manifestasi dari kemampuan jantung dan indikator dari denyut jantung ialah denyut nadi. ${ }^{8}$ Denyut jantung normal berkisar antara 60-100 denyut per menit. ${ }^{9}$ Pada individu yang tidak aktif antara lain individu dengan perilaku sedentary cenderung mempunyai frekuensi denyut jantung yang lebih tinggi sehingga otot jantung harus bekerja lebih keras pada setiap kontraksi. ${ }^{10}$

Berdasarkan permasalahan di atas maka penulis ingin meneliti hubungan perilaku sedentary dengan IMT, hipertensi, serta denyut jantung dengan batasan penelitian pada kegiatan dalam jam kerja atau dalam lingkungan perkerjaan pada subjek penelitian yang didasarkan faktor risiko sedentary yaitu pekerjaan yang banyak menghabiskan waktu duduk seperti halnya pegawai di RSUD Provinsi Sulawesi Utara. Menurut observasi dan wawancara pada pegawai, rumah sakit ini memiliki lingkungan kerja yang kecil dan operasional rumah sakit yang tergolong belum berjalan sepenuhnya.

\section{METODE PENELITIAN}

Penelitian ini merupakan penelitian observasional analitik dengan desain potong lintang. Pada penelitian ini dilakukan pengamatan langsung pada subyek yaitu pegawai struktural dan pegawai administrasi di RSUD Provinsi Sulawasi Utara dari bulan Oktober s/d November 2019 dengan rentang usia 25-50 tanpa kontraindikasi dalam pemeriksaan IMT dan tidak dalam pengobatan tekanan darah tinggi. Perilaku sedentary pada penelitian ini diukur menggunakan kuesioner Occupational Sitting and Physical Activity Questionnaire yang dikhususkan untuk perilaku subyek di tempat kerja.

\section{HASIL PENELITIAN}

Penelitian ini bertujuan untuk mengetahui adanya hubungan antara perilaku sedentary dengan IMT, tekanan darah, dan denyut jantung pada pegawai struktural dan pegawai administrasi di RSUD Provinsi Sulawesi Utara. Dari jumlah total 45 pegawai struktural dan pegawai administrasi, terdapat 37 pegawai yang memenuhi kriteria penelitian.

Tabel 1 memperlihatkan korelasi antar variabel. Pada output terlihat korelasi hubungan kuat variabel sedentary dengan tekanan darah sebesar 0,684. Korelasi variabel sedentary dengan indeks massa tubuh sebesar $-0,101$. Hubungan ini merupakan korelasi negatif yang menunjukkan hubungan berlawanan yaitu jika sedentary tinggi maka IMT rendah. Korelasi kategori sangat kuat didapatkan antara variabel sedentary dengan denyut jantung sebesar 0,796 . 
Tabel 1. Hasil uji korelasi Pearson dengan $\mathrm{N}=37$

\begin{tabular}{llccc}
\hline & & TD & IMT & $\begin{array}{c}\text { Denyut } \\
\text { jantung }\end{array}$ \\
\cline { 2 - 5 } Sedentary & Pearson Correlation &, $684^{* *}$ &,- 101 &, $796^{* *}$ \\
& Sig. (2-tailed) &, 000 &, 554 &, 000 \\
$\mathrm{~N}$ & 37 & 37 & 37 \\
\hline **Correlation is significant at the 0.01 level (2-tailed) & & \\
*Correlation is significant at the 0.05 level (2-tailed) & &
\end{tabular}

\section{BAHASAN}

Kenaikan IMT bergantung pada jumlah kalori yang diserap dari makanan, aktivitas fisik, dan metabolisme. ${ }^{11}$ Terdapat faktor-faktor lain yang turut berperan yaitu status ekonomi dan pekerjaan. Subyek penelitian ialah pegawai struktural dan administrasi yang memiliki aktivitas fisik dalam lingkup kerja yaitu umumnya dengan posisi duduk. ${ }^{12}$ Dalam penelitian ini tidak didapatkankan hubungan antara perilaku sedentary dan IMT. Hal ini dapat disebabkan karena jumlah subyek penelitian yang kurang dan juga tidak ditanyakan pola diet subjek serta aktivitas fisiknya di luar jam kerja. Hasil penelitian ini sejalan dengan penelitian yang dilakukan oleh Gresia dan Fatmah ${ }^{13}$ yang menunjukkan bahwa tidak terdapat hubungan antara aktivitas fisik dengan IMT oleh karena bervariasinya jenis aktivitas fisik yang dilakukan subyek penelitian pada waktu luang. Pada penelitian ini waktu luang subyek penelitian di luar jam kerja dipakai untuk pekerjaan rumah lainnya sehingga aktivitas sedentary di tempat kerja dapat diimbangi dengan aktivitas fisik di luar tempat kerja. Fuadiati ${ }^{14}$ melakukan penelitian terhadap ibu rumah tangga dan mendapatkan adanya hubungan positif yang sangat bermakna antara gaya hidup sedentary dengan obesitas.

Hasil penelitian ini mendapatkan adanya hubungan perilaku sedentary dengan tekanan darah yang tergolong kategori hubungan kuat. Oktaviarini et al, ${ }^{15}$ melakukan studi epidemiologi untuk menilai hubungan antara perilaku sedentary dan tekanan darah dan mendapatkan hasil yang tidak konsisten. Perilaku sedentary inter- aktif seperti penggunaan komputer dan mengemudi tampaknya menjadi faktor risiko independen untuk kejadian hipertensi dan perilaku sedentary non-aktif seperti menonton televisi yang tidak menunjukkan hubungan bermakna dengan kejadian hipertensi. ${ }^{15}$ Menurut penelitian Oematan ${ }^{16}$ pada remaja di salah satu kecamatan di Tanggerang disimpulkan adanya hubungan antara aktivitas berbasis layar dan aktivitas duduk dengan hipertensi obesitik. Penemuan ini ditunjang dengan pernyataan Oktaviarini et al, ${ }^{15}$ yaitu otot seseorang yang kurang aktivitas fisik cenderung mengendur sehingga pasokan peredaran darah akan terhambat yang menyebabkan resistensi perifer dan kerja jantung menjadi lebih berat.

Pada penelitian ini didapatkan hubungan yang sangat kuat antara perilaku sedentary dengan denyut jantung. Hal ini disebabkan seseorang yang kurang melakukan aktivitas fisik maka ototnya cenderung mengendur sehingga pasokan peredaran darah akan terhambat. ${ }^{15}$ Kenaikan denyut jantung disebabkan berkurangnya pasokan oksigen dan bahan bakar energi ke otot sehingga kerja jantung secara otomatis akan meningkat. Denyut jantung memiliki hubungan searah dengan meningkatnya beban kerja dan konsumsi oksigen. ${ }^{17}$ Semakin besar oksigen yang dibutuhkan oleh sel-sel tubuh maka curah jantung akan meningkat sehingga muncul mekanisme kompensasi dari saraf simpatik berupa peningkatan denyut jantung. ${ }^{15,18}$ Individu yang tidak aktif juga cenderung mempunyai frekuensi denyut jantung yang lebih tinggi sehingga otot jantung harus bekerja lebih keras pada setiap kontraksi. ${ }^{10}$ 


\section{SIMPULAN}

Pada pegawai struktural dan pegawai administrasi RSUD Provinsi Sulawesi Utara, tidak didapatkan hubungan antara perilaku sedentary dengan indeks massa tubuh tetapi terdapat hubungan kuat antara perilaku sedentary dengan variabel tekanan darah, serta hubungan sangat kuat antara perilaku sedentary dengan denyut jantung

\section{Konflik Kepentingan}

Penulis menyatakan tidak terdapat konflik kepentingan dalam studi ini.

\section{DAFTAR PUSTAKA}

1. Riset Kesehatan Dasar Nasional. Badan Penelitian dan Pengembangan Kesehatan, Kementerian Kesehatan RI. 2013.

2. Fadila I. Relasi perilaku Sedentary, gizi lebih, dan produktivitas kerja masyarakat perkotaan. Peran MST dalam mendukung urban lifestyle yang berkualitas 2016. [cited 2019 Aug 18]. Available from: http://repository.ut.ac.id/7087/

3. Physical inactivity a leading cause of disease and disability, warns WHO. World Health Organization, 2002. [cited 2019 Aug 18]. Available from: https://www. who.int/mediacentre/news/releases/ release23/en.com

4. Obesity and overweight. World Health Organization, 2018. [cited 2019 Aug 18]. Available from: https://www.who. int/news-room/fact-sheets/detail/ obesity-and-overweight.com.

5. Fajanah F. Faktor faktor determinan sedentary lifestyle pada remaja. Fakultas Kesehatan Masyarakat Universitas Muhammadiyah Semarang 2019 [Skripsi]. [cited 2019 Aug 18]. Available from: http://repository.unimus.ac.id/id/eprint/ 2503.

6. Riset Kesehatan Dasar Nasional tahun 2018. Jakarta: Badan Penelitian dan Pengembangan Kesehatan. Kementerian Kesehatan RI, 2018.

7. Infodatin hipertensi. Jakarta: Pusat Data dan Informasi, Kementerian Kesehatan Rl, 2014.

8. Lilik H, Hadi SS, Setya R. Pengaruh pemberian asupan cairan (air) terhadap profil denyut jantung pada aktivitas aerobic. Journal of Sport Sciences and Fitness. 2013;1(2).
9. All about heart rate (Pulse). American Heart Association, July 2015. [cited 2019 Aug 29]. Available from: https://www. heart.org/en/health-topics/high-bloodpressure/the-facts-about-high-bloodpressure/all-about-heart-rate-pulse

10. Sandi IN. Pengaruh latihan fisik terhadap frekuensi denyut nadi. Sport and Fitness Journal. 2016;4(2):1-6.

11. Abbas AK, Aster JC, Kumar V. Penyakit lingkungan dan nutrisi. In: Robbins Basic Pathology (9th ed). Elsevier Saunders, 2015; p. 303-5.

12. Sudikno S, Riyadi HR, Dwiriani CM, Syarief H. Faktor resiko overweight dan obesitas pada dewasa di Indonesia (Analisis Data Riset Kesehatan Dasar 2013). Gizi Indonesia. 2015;38(2):91104.

13. Gresia YH, Fatmah. Faktor-faktor yang mempengaruhi indeks massa tubuh (IMT) pada siswa SMA Marsudirini Bekasi tahun 2013. Fakultas Kesehatan Masyarakat, Universitas Indonesia. [cited 2019 Dec 2]. Available from: http://www.lib.ui.ac.id/naskahringkas/ 2015-09/S46608-gresia\%20yuli\%20h

14. Fuadiantif TF Hubungan gaya hidup sedentary dan stress dengan obesitas pada ibu rumah tangga [Skripsi]. Fakultas Psikologi Universitas Muhammadiyah Surakarta 2018. [cited 2019 Dec 2]. Available from: https: //docplayer.info/ 127767555-Hubungan -antara-gaya-hidup-sedentary-danstres-dengan-obesitas-pada-ibu-rumahtangga-skripsi.html

15. Oktaviarini E, Hadisaputro S, Chasani S, Suwondo A, Setyawan H. Faktor yang berisiko terhadap hipertensi pada pegawai di wilayah perimeter pelabuhan (Studi di Kantor Kesehatan Pelabuhan Kelas II Semarang). Jurnal Epidemiologi Kesehatan Komunitas. 2019;4(1):34-44.

16. Oematan GTS. Durasi tidur dan aktivitas sedentary sebagai faktor risiko hipertensi obesitik pada remaja di Kecamatan Pamulang Kota Tangerang Selatan Provinsi Banten [Tesis]. Yogyakarta: Universitas Gadjah Mada; 2016.

17. Rizqianti YS, Setiawan I, Hartono M. Korelasi antara denyut nadi dan indeks massa tubuh (IMT) tehadap hasil 
136 e-CliniC, Volume 8, Nomor 1, Januari-Juni 2020, hlm. 132-136

penampilan atlet senam ritmik POPDA

SD Kota Semarang tahun 2017.

Gelanggang Pendidikan Jasmani

Indonesia. 2018;2(1):68-74.

18. Gabor S. Chronic stress in the development of essential hypertension, role of rilmenidine in the treatment of stress induced hypertension. Am J Int Med. 2014; 2(1):1-5. 